\title{
PERANCANGAN PIPA PESAT, DAN DAYA KELUARAN PEMBANGKIT LISTRIK TENAGA AIR KOKOK PUTIH DESA BILOK PETUNG KECAMATAN SEMBALUN KABUPATEN LOMBOK TIMUR.
}

\author{
Barlian Mahendra, I Made Mara, Yesung Allo Padang. \\ Jurusan Teknik Mesin Fakultas Teknik Universitas Mataram \\ JI. Majapahit no 62, Mataram, NTB, kode pos 83122, Telp(0370)636126 \\ ext.128,(0370)636087 fax ( 0370 ) 636087 email: mesin_unram@telkom.net
}

\begin{abstract}
Inconsequent of decreasing fossil energy, It is necessary to developing an alternative energy source. One of the alternative energy that can be developing in Indonesia especially at Bilok Petung village, district of Sembalun, East Lombok Regency is water power station.

This design is to review power station plan in Koko Putih that will have finished. Inputs in this design are flow rate and head which are available in Koko Putih.

From this design, it is obtained that the inside penstock diameter $987 \mathrm{~mm}$ and the thickness penstock in head $286.72 \mathrm{~m}$ is $15.15 \mathrm{~mm}$, penstock material is carbon steel with specification ASTM A252 Grade 2. Head effective of Koko Putih water power plan is $249.603 \mathrm{~m}$. Output power of turbine is 3.9 MW and output power of generator is 3,6 MW.
\end{abstract}

Key word: penstock, head, power.

\section{PENDAHULUAN}

Perkembangan ilmu pengetahuan dan teknologi (IPTEK) telah membawa kemajuan-kemajuan besar baik dalam bidang kebudayaan, perubahan sosial dan penggunaan teknologi yang semakin mempermudah pencapaian tujuan manusia. Kemajuan yang didapat selalu diikuti dengan meningkatnya konsumsi energi. Dewasa ini tingkat kualitas kehidupan penduduk dari suatu negara tergantung pula pada tingkat konsumsi energi, karena kemajuan-kemajuan yang diperoleh tidak mungkin dicapai tanpa melibatkan penggunaan energi secara besar-besaran. (Ramdhani,dkk, 2008)

Kaitanya dengan permasalahan pembangkit listrik nasional yang sangat tergantung pada bahan bakar fosil, sangat rawan apabila ketersediaan minyak bumi dan batubara Indonesaia habis pada 10 25 tahun mendatang. Apalagi saat ini Indonesia semakin defisit energi. Pada sisi lain, sesungguhnya Indonesia mempunyai potensi ketersediaan energi luar biasa besarnya, yaitu sumber energi terbarukan, yang sering disebut sebagai energi alternatif berupa air (hidro, mini/mikro hidro), panas bumi, biomasa (limbah organik), sinar matahari (surya) dan angin. Sumber energi air yang telah dimanfaatkan untuk listrik hingga $14,2 \%$ (dari potensi 458,75 MW) dalam bentuk mini/mikro hidro, bentuk hidro $5,1 \%$ dari potensi setara 75,67 GW listrik, panas bumi $4,1 \%$ dari potensi $19,66 \mathrm{GW}$, biomasa $0,6 \%$ dari potensi $49,81 \mathrm{GW}$ serta matahari dan angin masih di bawah permil dari potensinya. (Ihwan.2009).

Untuk didaerah NTB khususnya pulau Lombok potensi energi air cukup menjanjikan untuk dikembangkan karena selain sebagi solusi untuk menghadapi masalah energi listrik, juga mempunyai banyak sungai dan kontur pegunungan yang memungkinkan didapatnya head dan debit yang cukup. Untuk PLTA potensinya bisa dikembangkan di Lombok khususnya di sungai Koko Putih, dari data hidrologi yang didapatkan, selain karena mempunyai aliran perennial atau mempunyai aliran sepanjang tahun, dan debit minimum dari sungai koko putih 1,88 m3/s, dan head tersedia 286,72 m. (Anonim I,2010)

Adapun tujuan dari perancangan ini adalah meninjau ulang pipa pesat, daya keluaran dan jenis turbin dan generator yang ada di PLTA koko putih.

\section{TINJAUAN PUSTAKA}

Salah satu solusi menghadapi masalah kelistrikan yaitu Sumber daya air yang mempunyai potensi yang cukup besar untuk menunjang kebutuhan sektor 
listrik.Peran PLTA/PLTMinihidro sebagai penunjang pembangkit yang ada masih berpotensi untuk dikembangkan, Namun biaya investasi PLTA/PLTM sangat besar, waktu pembangunan cukup lama sehingga harus dilakukan perencanaan yang mantap. (Anonim,2007)

Jika potensi air yang ada di NTB mampu dikembangkan optiimal akan menghasilkan $\pm 30 \mathrm{MW}$, cukup untuk memasok $15 \%$ dari kebutuhan listrik PLN di NTB, dan cukup untuk memasok kebutuhan listrik seluruh wilayah timur Kabupaten Lombok Timur sebesar 41,36 MW pada tahun $2011 .($ Ihwan,2009)

Pembangkit Listrik Tenaga Air (PLTA). Pembangkit Listrik Tenaga Air adalah suatu bentuk perubahan tenaga dari tenaga air dengan ketinggian dan debit tertentu menjadi tenaga listrik, dengan menggunakan bantuan turbin air dan generator

Bentuk pembangkit tenaga air adalah bervariasi, tetapi prinsip kerjanya adalah sama, yaitu ; (Perubahan tenaga potensial air menjadi tenaga listrik). Perubahan memang tidak langsung, tetapi berturut-turut melalui perubahan sebagai berikut :

- Tenaga potensial yang ada pada air dialirkan sehingga menjadi Tenaga kinetik.

- Tenaga kinetik oleh turbin diubah menjadiTenaga mekanik

- Tenaga mekanik potaran poros turbin diteruskan ke generator sehingga terbentuk Tenaga listrik

Tenaga potensial adalah tenaga air karena berada pada ketinggian. Tenaga kinetik adalah tenaga air karena mempunyai kecepatan. Tenaga mekanik adalah tenaga kecepatan air yang terus memutar kincir/turbin. Tenaga listrik adalah hasil dari generator yang berputar akibat berputarnya turbin.Prinsip kerja PLTA yang paling utama adalah memanfaatkan semaksimal mungkin energi air yang dapat ditangkap oleh peralatan utamanya yang disebut turbin/kincir air. (Warsito dkk, 2005)

\subsection{Komponen PLTA.}

PLTA sendiri mempunyai beberapa komponen yaitu bendungan, saluran pengambilan, bak penenang, pipa pesat, dan power house yang mana dalam power house ini terdapat turbin dan generator dan peralatan pendukung lainya.

\subsection{Pipa pesat.}

Untuk membawa air dari bak penenang ke turbin diperlukan pipa yang mampu menahan tekanan yang cukup tinggi, pipa ini disebut juga pipa pesat. Dasar perancangan pipa pesat ini adalah sama dengan perencanaan tangki dan vessel (bejana tekan); akan tetapi karena governor kontrol dan katup operasi turbin dapat mengakibatkan tekanan tiba tiba seperti water hammer maka perencanaannya perlu diperhatikan.

Apabila jarak antara bak penenang dan turbin pendek, pipa pesat yang digunakan satu batang pipa untuk satu turbin. Sedangkan untuk pembangkit yang mempunyai head yang tinggi atau jarak antara turbin dan bak penenang panjang maka digunakan satu batang pipa khusus untuk melayani beberapa turbin.Ada beberapa jenis dan bahan pipa pesat yaitu:
a. Pipa Carbon (Pipa baja)
b. Pipa spiral welded steel (Pipa baja spiral)
c. Pipa PVC
d. Pipa rolled welded steel (pipa baja gulung)

(Sharma K.N. Dandekar. M.M; 1991)

\subsection{Turbin Air}

Turbin air adalah alat untuk mengubah energi air menjadi energi puntir. Energi puntir ini kemudian diubah menjadi energi listrik oleh generator. Untuk pemilihan turbin sendiri digunakan diagram di bawah ini

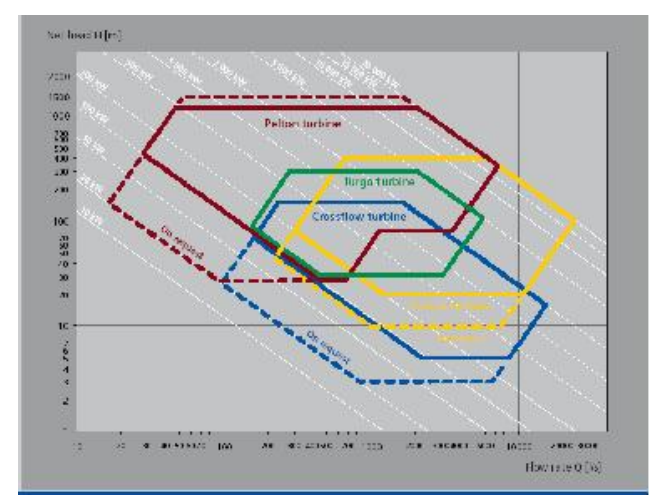

Gambar 1 : Grafik Klasifikasi turbin berdasarkan head dan debit.

(Sumber): Anonim I, 2010

\subsection{Generator.}

Generator adalah suatu alat yang berfungsi mengubah energi mekanik menjadi energi listrik, sedangkan jenis generator yaitu: generator singkron dan 
asingkron. Generator yang digunakan pada stasiun tenaga air biasanya terdiri dari mesin singkron tiga fase, dengan putaran antara 70 sampai $1000 \mathrm{rpm}$.

Berdasarkan arah porosnya, generator dibagi dalam jenis poros datar (horizontal) dan poros tegak (vertical). Jenis poros datar biasanya digunakan pada PLTA sekala kecil dengan putaran tinggi. Untuk jenis poros tegak biasanya digunakan untuk PLTA sekala besar dengan putaran rendah. Kelebihan dari generator poros tegak yaitu ruang yang dibutuhkan relatif kecil. (Arismunandar, Kuwahara,1982)

\section{METODE PERANCANGAN}

\subsection{Dasar-Dasar Perancangan}

Perencanaan pipa pesat dan perhitungan daya keluaran turbin ini didasarkan atas keinginan untuk mengetahui bagaimana sistem perpipaan pipa pesat yang baik dan benar pada sebuah pembangkit listrik tenaga air. Selain itu, besarnya head efektif dan daya keluaran dari head dan debit yang tersedia belum diketahui.

\subsection{Alur Kerja}

Langkah awal yang dilakukan dalam perancangan pipa pesat ini adalah dengan melakukan study literature mengenai materi-materi yang menunjang dalam perancangan ini. Perancangan ini dilakukan berdasarkan keriteria debit aliran dan head yang terdapat pada sungai Koko Putih.

Setelah literature terkumpul dan data mengenai headtersedia dan debit aliran air di sungai kokok putihdidapatkan, maka akan menghitung dimensi pipa, kemudian mulai melakukan perhitunganperhitungan untuk mengetahui losses enegi dan debit efektif pada pipa. Dari hasil perhitungan lossis energi dan debit efektif pipa ini akan dihitung head efektif, dengan cara mengurangi head tersedia atau debit tersedia deagan head losses baik dibelokan maupun di sepanjang pipa.

Setelah head losses dihitung, selanjutnya akan dihitung daya dari turbin yang nantinya digunakan dalam pemilihan jenis turbin. Setelah jenis turbin didapat maka akan dihitung daya yang didapat dari keluaran generator, daya keluaran generator ini disebut juga daya keluaran PLTA, selanjutnya setelah daya keluaran ini didapat maka akan dilakukan pemilihan generator yang dibutuhkan untuk PLTA ini.

Setelah melakukan perancangan maka penulis akan melakukan survey lapangan untuk membandingkan hasil perhitungan kami dengan yang ada di PLTA koko putih.

\section{HASIL DAN PEMBAHASAN}

Pada perencanaan ini dilakukan perhitungan berupa perhitungan dimensi pipa pesat, head loss pada pipa pesat, perhitungan potensi daya keluaran yang nantinya akan digunakan untuk memilih turbin dan generator yang cocok untuk pembangkit listrik tenaga air Kokok Putih. Data masukan dari perencanaan ini adalah head dan debit yang tersedia pada sungai kokok putih. Adapun data head terssedia atau head statis 286,72 dan sesuai grafik Flow Duration Curve debit tersedia pada sungai kokok putih $\mathrm{m}$ dan $1,88 \mathrm{~m} 3 / \mathrm{s}$.

\subsection{Perhitungan Dimensi Pipa Pesat. \\ a. Perhitungan tekanan hidrostatik. Tekanan hidrostatik dihitung berdasarkan persamaan

$$
p=\rho \times g \times h_{\text {statis }}
$$


Tabel:1 Perhitungan tekanan hidrostatis pada tiap ruas.

\begin{tabular}{|c|c|c|c|c|c|c|}
\hline NO & $\begin{array}{c}\text { level } \\
\text { (meter) }\end{array}$ & POSISI & $\begin{array}{l}\mathrm{H} \\
(\mathrm{m}) \\
\end{array}$ & $\begin{array}{c}\text { Grafitasi } \\
\mathrm{m} / \mathrm{s} 2 \\
\end{array}$ & $\begin{array}{c}\text { Masa Jenis } \\
\text { kg/m3 }\end{array}$ & $\begin{array}{c}\text { Tekanan Hidrostatis } \\
\mathrm{Pa}\end{array}$ \\
\hline 1 & $661,280 \mathrm{~s} / \mathrm{d} 652,775$ & RUAS 1 & 8.51 & 9.8 & 996.00 & 83015.604 \\
\hline 2 & 652,775 s/d 651,220 & RUAS 2 & 10.06 & 9.8 & 996.00 & 98193.648 \\
\hline 3 & $651,220 \mathrm{~s} / \mathrm{d} 650,502$ & RUAS 3 & 10.78 & 9.8 & 996.00 & 105201.902 \\
\hline 4 & $650,502 \mathrm{~s} / \mathrm{d} 622,157$ & RUAS 4 & 39.12 & 9.8 & 996.00 & 381871.778 \\
\hline 5 & 622,157 s/d 615,577 & RUAS 5 & 45.70 & 9.8 & 996.00 & 446097.842 \\
\hline 6 & 615,577 s/d 605,806 & RUAS 6 & 55.47 & 9.8 & 996.00 & 541470.619 \\
\hline 7 & 605,806 s/d 589,706 & RUAS 7 & 71.57 & 9.8 & 996.00 & 698619.499 \\
\hline 8 & 589,706 s/d 578,985 & RUAS 8 & 82.30 & 9.8 & 996.00 & 803265.036 \\
\hline 9 & $578,985 \mathrm{~s} / \mathrm{d} 566.209$ & RUAS 9 & 95.07 & 9.8 & 996.00 & 927969.017 \\
\hline 10 & 566,209 s/d 536,347 & RUAS 10 & 124.93 & 9.8 & 996.00 & 1219446.026 \\
\hline 11 & 536,347 s/d 533,00 & RUAS 11 & 128.28 & 9.8 & 996.00 & 1252115.424 \\
\hline 12 & $533,00 \mathrm{~s} / \mathrm{d} 532,111$ & RUAS 12 & 129.17 & 9.8 & 996.00 & 1260792.775 \\
\hline 13 & $532,111 \mathrm{~s} / \mathrm{d} 523,822$ & RUAS 13 & 137.46 & 9.8 & 996.00 & 1341700.046 \\
\hline 14 & 523,822 s/d 515,437 & RUAS 14 & 145.84 & 9.8 & 996.00 & 1423544.354 \\
\hline 15 & 515,437 s/d 499,477 & RUAS 15 & 161.80 & 9.8 & 996.00 & 1579326.722 \\
\hline 16 & 499,477 s/d 493,03 & RUAS 16 & 168.25 & 9.8 & 996.00 & 1642254.600 \\
\hline 17 & 493,93 s/d 489,746 & RUAS 17 & 171.53 & 9.8 & 996.00 & 1674309.067 \\
\hline 18 & 489,746 s/d 479,77 & RUAS 18 & 181.51 & 9.8 & 996.00 & 1771682.808 \\
\hline 19 & $479,77 \mathrm{~s} / \mathrm{d} 422,606$ & RUAS 19 & 238.67 & 9.8 & 996.00 & 2329649.179 \\
\hline 20 & 422,606 s/d 374,56 & RUAS 20 & 286.72 & 9.8 & 996.00 & 2798616.576 \\
\hline
\end{tabular}

\section{b. Perhitungan Diameter Dalam Pipa}

Perhitungan diameter pipa berdasarkan persamaan Gordon-Penman berikut ini;

Untuk $\mathrm{Q}=1,88 \mathrm{~m} / \mathrm{s}$

$\mathrm{D}=0,72\left(\mathrm{Q}^{0,5}\right)$

$\mathrm{D}=0,72\left(1,88^{0,5}\right)$

$\mathrm{D}=0,987 \mathrm{~m}$

Sehingga kecepatan alirannya dihitung sebagai berikut;

$\mathrm{Q}=\mathrm{A} \times \mathrm{V}$

$v=\frac{Q}{1 / 4 \pi D^{2}}$

$$
\begin{aligned}
& \mathrm{v}=\frac{1,88}{1 / 4 \times 3,140,987^{2}} \\
& \mathrm{v}=2,45 \mathrm{~m} / \mathrm{s}
\end{aligned}
$$

\section{c. Perhitungan Tebal Pipa Pesat}

Untuk pipa dengan standar ASME A252 Grade 2 mempunyai yeild strength 35.000 psi (lampiran 3) atau 2460.74 $\mathrm{kgf} / \mathrm{cm}^{2}$ dan diambil faktor keamanan 2,25 untuk kriteria kondisi pipa berubah ubah, Selain itu juga tekanan hidrostatik maksimumnya adalah 2798616.576 $\mathrm{Pa}$ atau $28.5379 \mathrm{kgf} / \mathrm{cm}^{2}$ dan efisiensi las-lasan $85 \%$ Sehingga tebal pipa per segmen tertera pada tabel dibawah ini 
Tabel: 2 Perhitungan Tebal Pipa Per Segmen.

\begin{tabular}{|c|c|c|c|c|c|c|c|c|}
\hline NO & $\begin{array}{c}\text { level } \\
\text { (meter) }\end{array}$ & POSISI & $\begin{array}{c}\mathrm{H} \\
(\mathrm{m})\end{array}$ & $\begin{array}{c}\mathrm{S} \\
\mathrm{kgf} / \mathrm{cm} 2\end{array}$ & $\begin{array}{c}\mathrm{D} \\
\mathrm{cm}\end{array}$ & $\begin{array}{c}\mathrm{t} \\
\text { ASME } \\
(\mathrm{mm})\end{array}$ & $\begin{array}{c}\mathrm{t} \\
\text { warnick } \\
(\mathrm{mm})\end{array}$ & $\begin{array}{c}\text { Tebal Terpasang } \\
(\mathrm{mm})\end{array}$ \\
\hline \hline 1 & $661,280 \mathrm{~s} / \mathrm{d} 652,775$ & RUAS 1 & 8.51 & 2461 & 98.70 & 3.82 & 0.45 & 10.0 \\
\hline 2 & $652,775 \mathrm{~s} / \mathrm{d} 651,220$ & RUAS 2 & 10.06 & 2461 & 98.70 & 3.91 & 0.53 & 10.0 \\
\hline 3 & $651,220 \mathrm{~s} / \mathrm{d}$ 650,502 & RUAS 3 & 10.78 & 2461 & 98.70 & 3.94 & 0.57 & 10.0 \\
\hline 4 & $650,502 \mathrm{~s} / \mathrm{d} 622,157$ & RUAS 4 & 39.12 & 2461 & 98.70 & 5.44 & 2.07 & 10.0 \\
\hline 5 & $622,157 \mathrm{~s} / \mathrm{d} 615,577$ & RUAS 5 & 45.70 & 2461 & 98.70 & 5.79 & 2.41 & 10.0 \\
\hline 6 & $615,577 \mathrm{~s} / \mathrm{d} 605,806$ & RUAS 6 & 55.47 & 2461 & 98.70 & 6.31 & 2.93 & 10.0 \\
\hline 7 & $605,806 \mathrm{~s} / \mathrm{d} 589,706$ & RUAS 7 & 71.57 & 2461 & 98.70 & 7.16 & 3.78 & 10.0 \\
\hline 8 & $589,706 \mathrm{~s} / \mathrm{d} 578,985$ & RUAS 8 & 82.30 & 2461 & 98.70 & 7.73 & 4.35 & 10.0 \\
\hline 9 & $578,985 \mathrm{~s} / \mathrm{d} 566.209$ & RUAS 9 & 95.07 & 2461 & 98.70 & 8.41 & 5.02 & 10.0 \\
\hline 10 & $566,209 \mathrm{~s} / \mathrm{d} 536,347$ & RUAS 10 & 124.93 & 2461 & 98.70 & 10.00 & 6.60 & 10.0 \\
\hline 11 & $536,347 \mathrm{~s} / \mathrm{d} 533,00$ & RUAS 11 & 128.28 & 2461 & 98.70 & 10.18 & 6.78 & 10.0 \\
\hline 12 & $533,00 \mathrm{~s} / \mathrm{d} 532,111$ & RUAS 12 & 129.17 & 2461 & 98.70 & 10.23 & 6.83 & 10.0 \\
\hline 13 & $532,111 \mathrm{~s} / \mathrm{d} 523,822$ & RUAS 13 & 137.46 & 2461 & 98.70 & 10.67 & 7.26 & 10.0 \\
\hline 14 & $523,822 \mathrm{~s} / \mathrm{d} 515,437$ & RUAS 14 & 145.84 & 2461 & 98.70 & 11.11 & 7.71 & 10.0 \\
\hline 15 & $515,437 \mathrm{~s} / \mathrm{d} 499,477$ & RUAS 15 & 161.80 & 2461 & 98.70 & 11.96 & 8.55 & 10.0 \\
\hline 16 & $499,477 \mathrm{~s} / \mathrm{d} 493,03$ & RUAS 16 & 168.25 & 2461 & 98.70 & 12.31 & 8.89 & 10.0 \\
\hline 17 & $493,93 \mathrm{~s} / \mathrm{d} 489,746$ & RUAS 17 & 171.53 & 2461 & 98.70 & 12.48 & 9.06 & 10.0 \\
\hline 18 & $489,746 \mathrm{~s} / \mathrm{d} 479,77$ & RUAS 18 & 181.51 & 2461 & 98.70 & 13.02 & 9.59 & 10.0 \\
\hline 19 & $479,77 \mathrm{~s} / \mathrm{d} 422,606$ & RUAS 19 & 238.67 & 2461 & 98.70 & 16.07 & 12.61 & 13.0 \\
\hline 20 & $422,606 \mathrm{~s} / \mathrm{d} 374,56$ & RUAS 20 & 286.72 & 2461 & 98.70 & 18.65 & 15.15 & 15.0 \\
\hline
\end{tabular}

Dari hasil perhitungan berdasarkan persamaan yang yang diberikan ASME pada persamaan 2 didapat tebal maksimum batang pipa adalah $18,95 \mathrm{~mm}$ dan hasil perhitunga berdasarkan persamaan warnick didapat $15,15 \mathrm{~mm}$ sedangkan yang terpasang adalah $15,0 \mathrm{~mm}$.

Perhitungan tebal minimum pipa pesat digunakan untuk mendapatkan kekakuan dan perlindungan terhadap korosi, selain itu faktor keamanan yang diambil adalah 2,25. Sehingga tebal minimum di hitung dengan persamaan).

Sehingga

$$
t=\frac{D+50}{400} \times s f
$$

$$
\begin{gathered}
t=\frac{98,7+50}{400} \times s f \\
t=0,84 \mathrm{~mm}
\end{gathered}
$$

\subsection{Perhitungan Head Loss}

\section{a. Perhitungan mayor losees.}

Yang menjadi masukan dari perhitungan ini adalah; panjang total pipa yaitu $1745.57 \mathrm{~m}$, (lampiran 5) debit tersedia $1,88 \mathrm{~m} 3 / \mathrm{s}$, head tersedia 286,72 m, material pipa baja karbon dengan spesifikasi ASTM A252 Grade2, sehingga mayor losses dihitung dengan persamaan Darsy-Weisbach pada persamaann sebagai berikut:

$$
\mathrm{hf}=\frac{\lambda \mathrm{lv}^{2}}{2 \mathrm{gD}}
$$

Untuk faktor gesekan ditentukan dengan moody diagram, yang mana $\mathrm{Kc}$ didapat dari tabel sama dengan 0,045 untuk pipa welded steel, sehingga Rougness ratio dihitung dengan rumus

$$
\begin{aligned}
\text { Rougness Ratio } & =\frac{\mathrm{k}}{\mathrm{D}} \\
\text { Rougness Ratio } & =\frac{0,045}{0,987} \\
\text { Rougness Ratio } & =0,0455927
\end{aligned}
$$

Reynolds Number dihitung dengan persamaan

$$
\mathrm{Re}=\frac{\mathrm{vD}}{\mathrm{v}}
$$

Dari tabel, Untuk viskositas kinematis air pada temperatur $30^{\circ} \mathrm{C}$ yaitu $0,801 \times 10-6 \mathrm{~m} 2 / \mathrm{s}$ sehingga:

$$
\begin{aligned}
\operatorname{Re} & =\frac{2,45 \times 0,987}{0.801 \times 10^{-6}} \\
\operatorname{Re} & =3,02 \times 10^{6} \\
& \text { Dari moody diagram pada di }
\end{aligned}
$$
dapat $\lambda \approx 0,068$

Dengan demikian:

$$
\begin{gathered}
\text { hf }=\frac{0,068 \times 1745.57 \times\left(2,45^{2}\right)}{2 \times 9,8 \times 0,987} \\
\text { hf }=36,72 \mathrm{~m}
\end{gathered}
$$




\section{b. Perhitungan minor loses}

Pada sisi masukan pada bak penenang

Digunakan persamaan sebagai berikut:

$$
\mathrm{hf}_{\text {masukan }}=\mathrm{K}_{\mathrm{c}} \frac{\mathrm{v}^{2}}{2 \times \mathrm{g}}
$$

Untuk Kc dapat dilihat pada gambar maka diambil nilai tengah yaitu 0,45 untuk PLTA koko putih, sehingga:

$$
\begin{aligned}
\mathrm{hf}_{\text {masukan }} & =0,45 \frac{2,45^{2}}{2 \times 9,8} \\
\mathrm{hf}_{\text {masukan }} & =0,137 \mathrm{~m}
\end{aligned}
$$

> Pada belokan pipa

Perhitungan head los pada belokan pipa ini digunakan persamaan (2.25) sebagai berikut ;

$$
\mathrm{hf}_{\text {belokan }}=\mathrm{K}_{\mathrm{b}} \frac{\mathrm{v}^{2}}{2 \times \mathrm{g}}
$$

Untuk harga $\mathrm{Kb}$ dapat dilihat pada tabel koefisien belokan sehingga, dari persamaan di atas maka didapat losses energi pada belokan pipa tertera pada tabel sebagai berikut:

\section{Head loss pada reducer}

Pada ujung pipa dekat power house, pipa yang masuk turbin dibagi dua dan mengecil menjadi masing masing mempunyai diameter dalam $490 \mathrm{~mm}$ dengan panjang $5,4 \mathrm{~m}$ sehingga terjadi kehilangan energi. Untuk menghitung kehilangan energi ini digunakan persamaan sebagai berikut

$$
\mathrm{hf}_{\text {reducer }}=\mathrm{K}_{\mathrm{rd}} \frac{\mathrm{v}^{2}}{2 \cdot \mathrm{g}}
$$

Dimana besar sudut $\theta$ adalah $5^{0}$ sehingga dari tabel koefisien reducer didapat $\mathrm{K}_{\mathrm{rd}}$ adalah 0,12. Sehingga.

$$
\begin{aligned}
\mathrm{hf}_{\text {reducer }} & =0,112 \frac{2,45^{2}}{2 \times 9,8} \\
\mathrm{hf}_{\text {reducer }} & =0,034
\end{aligned}
$$

Karena pada pipa pesat terdapat dua reduser maka kehilangan energinya dikalikan dua sehingga:

$$
\begin{aligned}
& \mathrm{hf}_{\text {reducer }}=0,03 \times 2 \\
& \text { hf }_{\text {reducer }}=0,06
\end{aligned}
$$

Sehingga head loss total adalah:

$$
\begin{gathered}
\mathrm{h}_{\text {loss }}=\text { Minor Loss }+ \text { mayor Loss } \\
\mathrm{h}_{\text {loss }}=\mathrm{hf}+\mathrm{hf}_{\text {masukan }}+\mathrm{hf}_{\text {belokan }} \\
\quad+\mathrm{hf}_{\text {reducer }} \\
\mathrm{h}_{\text {loss }}=36,72 \mathrm{~m}+0,137 \mathrm{~m} \\
\quad+0,26 \mathrm{~m}+0,06 \mathrm{~m} \\
\mathrm{~h}_{\text {loss }}=37,117 \mathrm{~m}
\end{gathered}
$$

\subsection{Perhitungan Head Efektif}

Untuk menghitung head efektif ini digunakan persamaan (2.21) sebagai berikut.

$$
\begin{gathered}
\mathrm{H}_{\text {efektif }}=\mathrm{H}_{\text {tersedia }}-\mathrm{h}_{\text {loss }} \\
\text { sehingga } \\
\mathrm{H}_{\text {efektif }}=286.72-37,117 \\
\boldsymbol{H}_{\text {efektif }}=249,603 \mathrm{~m}
\end{gathered}
$$

\subsection{Perhitungan Daya Hidrolis.}

Untuk menghitung nilai daya hidrolis digunakan persamaan sebagai berikut:

$$
\begin{aligned}
& \mathbf{p}=\rho . \text { g. } \mathrm{H}_{\text {efektif }} \cdot \mathbf{Q} \\
& \mathbf{p}=996 \mathrm{~kg} / \mathrm{m}^{3} \cdot 9,8 \mathrm{~m} / \mathrm{s}^{2} \cdot 249,603 \mathrm{~m} \cdot 1,88 \mathrm{~m}^{3} / \mathrm{s} \\
& \mathbf{p}=4580290,929 \text { watt }
\end{aligned}
$$

\subsection{Perhitungan Daya Keluaran dan} pemilihan Turbin

Untuk evaluasi beban keluaran turbin, nilai yang memadai dari efisiensi turbin dapat ditentukan berdasarkan grafik pada gambar: 2 yaitu $85 \%$ sehingga daya keluaran turbin menjadi;

$$
\begin{aligned}
& \mathbf{P}_{\text {turbin }}=\mathrm{P} \times \eta_{\text {turbin }} \\
& \mathbf{P}_{\text {turbin }}=4580290,929 \times 0,85 \\
& \mathbf{P}_{\text {turbin }}=389806,897 \mathrm{watt} \\
& \mathbf{P}_{\text {turbin }}=3,9 \mathrm{MW}
\end{aligned}
$$

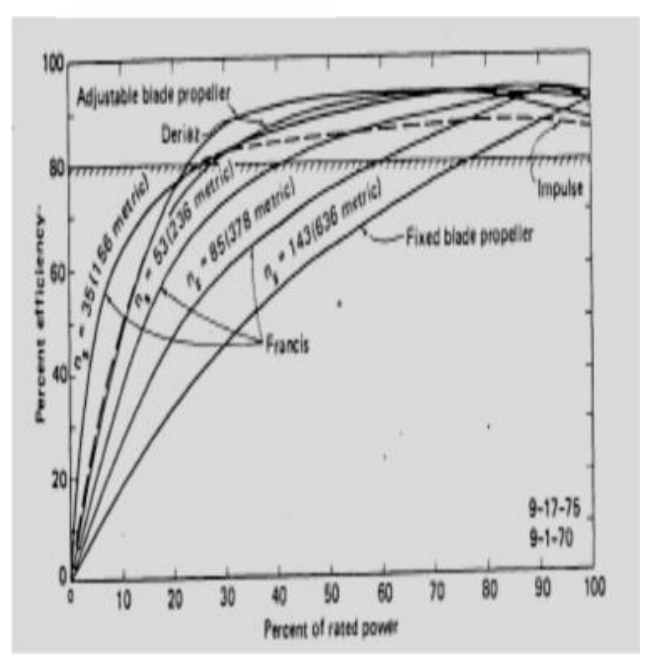

Gambar:2 Grafik penentuan efisiensi turbin. (Sumber: c.c warnick 1984.)

Dari kapasitas daya keluaraan turbin di atas maka diambil turbin 
dengan kapasitas $3.9 \mathrm{MW}$ atas dasar pertimbangan debit minimum maka turbin dibagi dua yang masing-masing $1.95 \mathrm{MW}$.

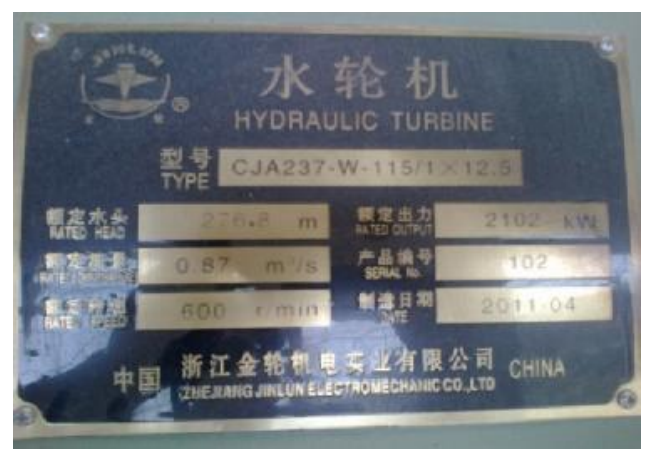

Gambar: 3 spesifikasi turbin yang terpasang

Berdasarkan data head dan debit yang ada pada sungai koko putih, maka dapat ditentukan kriteria turbin yang cocok berdasarkan gambar grafik 1 yaitu Turbin Pelton.

Jenis Turbin yang terpasang pada PLTA koko putih yaitu turbin pelton poros horizontal dengan kapasitas daya sebesar 2,1 MW sebanyak dua unit turbin seperti terlihat pada gambar berikut ini.

\subsection{Perhitungan Daya Keluaran Generator}

Dalam perhitungan daya generator atau daya keluaran PLTA digunakan persamaan (2.29) sebagai berikut.

$\mathbf{P}_{\text {generator }}=\eta_{\text {generator }} \times \mathbf{P}_{\text {turbin }}$

Efisiensi generator sendiri besarnya $85 \%$ sehingga:

$$
\begin{aligned}
& \mathbf{P}_{\text {generator }}=0,85 \times 1,95 \\
& \mathbf{P}_{\text {generator }}=1,56 \mathrm{MW}
\end{aligned}
$$

Untuk kapasitas daya generator
yang terpasang padar sebuah
pembangkit setidaknya 10 sampai $20 \%$
lebih besar dari hasil perhitungan daya
generator dengan demikian
kapasitasnya adalah:

$$
\mathbf{P}_{\text {gen terpasang }}=1560+(1560 \times 20 \%)
$$

$$
=1872 \mathrm{~kW}
$$

Sehingga besar daya yang terpasang hasil perhitungan adalah $2 \times 1872 \mathrm{~kW}$

Dalam pemilihan kapasitas daya yang terpasang pada PLTA digunakan persamaan sebagai berikut:

$$
\begin{gathered}
\mathbf{P}_{\text {semu }}=\frac{\mathbf{p}_{\text {generator }}}{\text { cos }} \\
\cos \Phi=\text { faktor daya }(0,80) \\
\text { Maka daya semu generator }
\end{gathered}
$$

$$
\begin{aligned}
& \mathbf{P}_{\text {semu }}=\frac{\mathbf{P}_{\text {generator }}}{\cos \Phi} \\
& \mathbf{P}_{\text {semu }}=1872 / 0.8 \\
& \mathbf{P}_{\text {semu }}=2340 \mathrm{kVA}
\end{aligned}
$$

Sedangkan daya generator yang terpasang pada PLTA Koko Putih yaitu $2 \times 2.018 \mathrm{~kW}$ atau seperti pada gambar berikut ini.

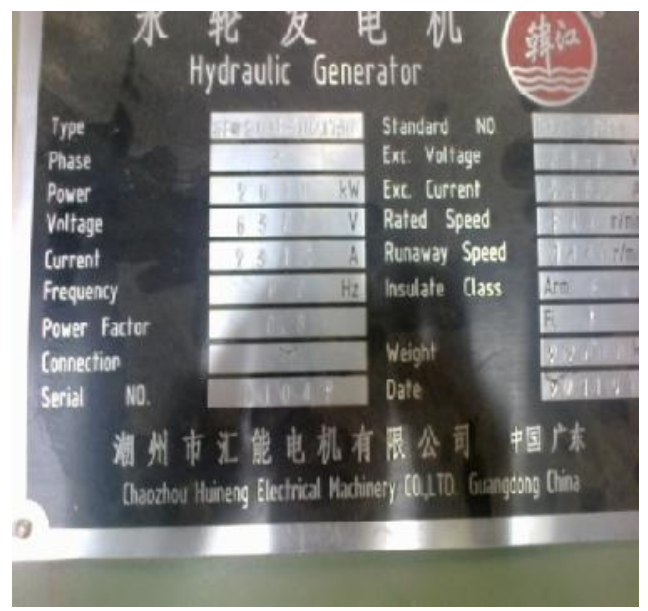

Gambar: 4 generator yang terpasang.

\section{KESIMPULAN DAN SARAN \\ 5.1. KESIMPULAN}

Dari hasil perhitungan ini dapat ditarik beberapa kesimpulan sebagai berikut:

1. Diameter dalam pipa pesat hasil perhitungan kami untuk PLTA Koko Putih $987 \mathrm{~mm}$ dan $507 \mathrm{~mm}$ sedangkan pipa pesat yang terpasang pada PLTA Koko Putih di antara keduanya yaitu $900 \mathrm{~mm}$.

2. Berdasarkan hasil perhitunga tebal pipa pesat maksimum pada level turbin yaitu $374,56 \mathrm{~m}$ adalah 15,15 $\mathrm{mm}$ dan ketebalan minimumnya adalah 0,84 $\mathrm{mm}$, sedangkan ketebalan pipa pesat yang terpasang pada PLTA koko putih pada level $374,56 \mathrm{~m}$ adalah $15,0 \mathrm{~mm}$ dan ketebalan minimumnya adalah 10 $\mathrm{mm}$.

3. Head losses total pada pipa pesat sebesar $37,117 \mathrm{~m}$ sehingga head efektif yang didapat adalah 249,63 $\mathrm{m}$.

4. Berdasarkan kriteria debit dan head yang ada pada koko putih, Jenis 
turbin yang dipakai pada PLTA koko putih adalah Turbin Pelton.

5. Daya keluaran turbin pada PLTA koko putih adalah 3,9 MW yang nantinya dibagi dua masing-masing $1.95 \mathrm{MW}$ ini didasarkan pertimbangan debit minimum, sedangkan yang terpasang yang terpasang pada PLTA koko putih memiliki kapasitas 2,1 MW berjumlah dua unit.

6. Untuk daya generator terpasang hasil perhitungan yaitu $2 \times 1872 \mathrm{~kW}$, dan yang terpasang yang terpasang pada PLTA koko putih lebh besar yaitu 2 x $2018 \mathrm{~kW}$.

\subsection{SARAN}

Untuk analisa pipa pesat baik itu, dimensi, head losses, dan jenis aliran sebaiknya menggunakan program komputer agar didapat hasil yang lebih akurat.

\section{DAFTAR PUSTAKA}

Anonim; 2010 Laporan Studi Kelayakan Pembangunan PLTA Koko Putih,PT. Nusantara Indo Energi, Jakarta.Internet:

Anonim I; 2010,Turbines worldwide, Wasserkrft Volk AG, www.wkv-ag.com.Waktu diakses 03:11 am tanggal 17 Mei 2012
Arismunandar, Kuwahara;1982,Buku Pegangan Teknik Tenaga Listrik Jilid I, P.T,Pradaya Paramita, Jakarta.

Ihwan;2009,Potensi pengembangan Energi Listrik Tersebar Di Kabupaten Lombok Timur, http://suryawan12.wordpres s.com/category/listrikterbarukan-ntb/Waktu diakses 03:11 am tanggal 17 Mei 2012

Ramdhani, dkk, Studi Perencanaan PLTMH 1x12 kW sebagai Desa Mandiri Energi di Desa Karangsewu, Cisewu, Garut, Jawa Baratm, Institut Teknologi Sepuluh Nopember, Surabaya

Sharma K.N. Dandekar. M.M; 1991, Pembangkit Listrik Tenaga Air, UI-press, Jakarta.

Warnick CC,1984, Hydropower Engineering,Prentice-Hall. Inc., Englewood Cliffs, NJ, New Jersy.

Warsito s, dkk, 2005, Studi Awal Perencanaan Sistem Mekanikal Dan Kelistrikan Pembangkit Listrik Tenaga Mini-Hidro, Teknik Elektro, Fak. Teknik Universitas Diponegoro, Semarang. 